\title{
The effect of good corporate governance on banking profitability
}

\section{Wagner Vicente-Ramos ${ }^{a}$, Keythi Gianella Cruz Reymundo ${ }^{a}$, Lizbbet Judit Espinoza Paria ${ }^{a}$, Nei- sha Maclobia Nuñez Rudas ${ }^{a}$ and Pedro Bernabe Venegas Rodriguez ${ }^{a}$}

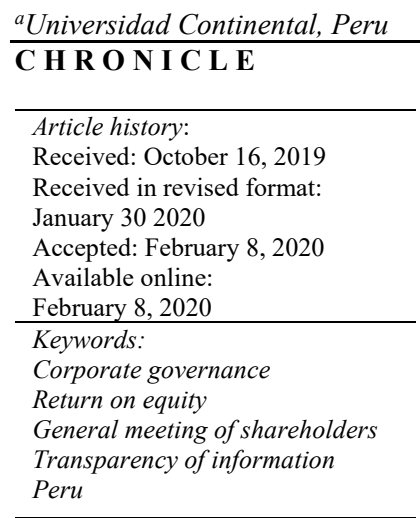

\begin{abstract}
A B S T R A C T
The objective of this paper is to determine the impact of the variables of good corporate governance on profitability by equity of the banks of Peru during the period $2009-2018$. The regression analysis of panel data was applied on a sample of 13 banks in Peru listed on the Lima Stock Exchange. Through an econometrics model it was obtained as a result that there was a significant direct relationship between the general meeting of shareholders and return on equity $(\mathrm{p}<0.05)$, which indicates that, the greater the integration of the General Meeting of shareholders in banking companies, the greater the profitability of equity for shareholders; which also shows that, the greater the transparency of information, the greater the profitability of equity for shareholders. This evidence provides beneficial information for supervisory authorities, stakeholders and academics.
\end{abstract}

C) 2020 by the authors; licensee Growing Science, Canada

\section{Introduction}

In a complex and dynamic business environment, a good corporate governance system is needed that increases the profitability of companies, improves job performance and reduces risks. Technological restrictions, lack of financial resources and commercial knowledge and the cost of implementing and communicating corporate governance policies throughout the organization are some important barriers that many companies face, especially small businesses (Pham et al., 2020). The purpose of a corporation is the maximization of shareholder wealth, which is why managers are appointed. However, the decisions they make will not necessarily influence the achievement of this objective, that in most cases incurs multi-million-dollar losses in different corporations around the world (Kengkathran, 2019). In recent years there has been an increase in corporate scandals related to corruption, transformation, financial and accounting information that caused bankruptcy, the reduction in the price of the share and the expropriation of assets. That as a whole caused the decrease in the profitability of corporations such as: Toshiba Corporation, Tesco, McDonald, Nieschwietz, among others (Mohamad Kamal et al., 2019). The financial system is one of the most dynamic sectors of the Peruvian economy, contributing 2.2\% to the National Gross Domestic Product for the year 2018 (Banco Central de Reserva del Perú, 2018). Possessing a code of good corporate governance provides banking institutions with a regulatory framework to rate the conduct and transparency, reduces agency costs that affects the expected return and informs the shareholder of the risk to which the entity is affected (Rokibul Kabir et al., 2019). Given the importance of deregulation, globalization, increased risk and investor protection, as well as the positive role of the banking sector in economic growth, corporate governance is of significant importance for the sustainability of the banking industry, since corporate governance practices help generate sustainable value for the banking industry (Yatim \& Yusoff, 2014). Consequently, it was proposed to examine the impact of the main pillars of good corporate governance on the banks' equity return, an indicator measured through the equity return ratio (ROE). 


\section{Literary review}

\subsection{Corporate governance}

Corporate Governance is the management system within the business society, which includes procedures, activities (practices) and institutions (standards) established internally or by external forces. It refers primarily to the relationship between shareholders of the company (owners) and its administration (board and management). This relationship is defined in terms of rights, powers and responsibilities of each group (Ortiz, 2014). Corporate governance exists as a mechanism to deal with the separation of property and control, and the possible agency conflicts that this separation entails (Casas Tragodara, 2018). At the macroeconomic level, the capacity of economies facing financial crises improves. As happened in 2008 (Laffaye, 2008), corporate governance compliance allows the existence of more liquid and transparent markets.

\subsection{Code of good corporate governance for Peruvian companies}

Both the Organization for Economic Co-operation and Development (OECD 1999) and Basel Committee on Banking Supervision (BCBS 1999; BCBS 2006) constituted a set of principles attached to a code, for the good practices of the associations, through the delimitation of the structures of the company and the functions that correspond to each one of its actors. In Peru, to recognize the importance of the development of the capital market by promoting greater corporate transparency, as well as the described advantages of having good corporate governance practices in 2002, a committee formed by eight public sector entities was formed and from the private sector, chaired by the then National Supervisory Commission of Companies and Securities (CONASEV), today Superintendence of the Securities Market (SMV), with the purpose of establishing principles of good corporate governance applicable to Peruvian companies. As a result of this joint effort, in July 2002 the document Principles of Good Governance for Peruvian Societies was issued, which was based on the Principles for the Governance of Societies issued by the OECD; considering the particular characteristics of Peruvian companies, their shareholding structure and the legal framework in which they were developed (Bolsa de Valores de Lima, 2013). More than 10 years after the Principles of Good Governance for Peruvian Societies were issued, on February 23, 2012, the Committee for Updating Principles of Good Governance for Peruvian Societies was established, which was composed of 14 public institutions and private companies of Peru, which, led by the Superintendence of the Securities Market (SMV), published in 2013 the "Code of Good Corporate Governance for Peruvian Companies" (which updates the 2002 version). The adoption of good corporate governance practices by societies promotes a climate of respect for the rights of shareholders and investors in general; contributes to generate value, solidity and efficiency in societies; brings with it a better management of the risks to which they are exposed; facilitates access to the capital market; leads to a reduction in the cost of capital, as well as greater and better access to sources of financing and long-term investment; Among other advantages. Likewise, experience has shown that to the extent that the greater transparency and information, the greater the confidence that investors develop in the markets. Good corporate governance practices help mitigate the failures that exist in financial markets due to information asymmetry (Bolsa de Valores de Lima, 2013).

The Code of Good Corporate Governance for Peruvian Societies is divided into five pillars:

a) Shareholder rights: This pillar develops the importance of legal protection for minority and majority investors, thus improving governance ratings in less developed countries and encouraging capital movement (Black, Carvalho, \& Gorga, 2010).

b) General meeting of shareholders: The structure of the board of creditors in the generation of value is vitally important. After conducting an investigation in companies listed on the Indonesian stock exchange, it was determined that the structure of the shareholders' meeting has a significant effect on the quality of earnings. In summary, the pillar develops the role and participation of each member within the board (Amin, Pirzada, Puspita, \& Arniati, 2019).

c) The board and senior management: This principle consists in transparency when choosing the members of the board of directors, for this purpose, the profiles on the specific requirements or competencies that should be developed for the position indicated are promulgated, as well as the rules and conditions for applying. Similarly, the reasons and mechanisms for termination by directors are defined and publicly understood (Superintendencia del Mercado de Valores, 2014).

d) Risk and compliance: This principle influences the creation of an appropriate culture in the companies that apply it. Not only does it increase value against markets and shareholders, but it will be visible to all Stakeholders. Consequently, it will increase the reputation vis-à-vis consumers, collaborators, suppliers and society in general. This will make it possible to establish better synergies, creating new business opportunities, ensuring their stability and market projection. Management boards must be responsible for the value of social reputation and, therefore, are sensible to respect and comply with good corporate governance, according to risk and compliance (Arrarte, 2019).

e) Transparency of information: This principle guarantees accurate and timely communication of all relevant business issues, including results, financial situation, ownership and governance bodies. Public disclosure is usually required, at a minimum, on an annual basis, although some countries require semi-annual or quarterly periodic disclosure, or even with high continuity for the development of materials that affect the company (Organización para la Cooperción y Desarrollo Económico, 2016).

f) Transparency is the delivery of information and openness in the decision-making process: The principle of transparency can be seen from the aspect of the delivery of vision, mission and provision, as well as the information provided to staff and the government (Rizqiani Rusydi, et al., 2019) 


\subsection{Bank profitability}

According to Babalola (2012) "Profitability, solvency and liquidity are important goals of banks, profitability is the most important one". Profitability quantifies the extent to which a company produces a rate of return that will be given to investors and how much profit the company obtains over a certain period. Profitability is measured using asset performance (ROA) and return on capital (ROE). Because the bank's profitability tends to persist over time, a dynamic model that controls a series of bank characteristics, fixed effects of the year and fixed effects of the bank is specified (Superintendencia del Mercado de Valores, 2014). Return on assets (ROA) determines the capacity of bank management in generating income by employing company assets at hand (Ongole \& Kusa, 2013). Return on equity (ROE) is also one of the many measures that determine how much profits are realized for the company concerning the total amount of shareholders' equity as indicated on a balance sheet. ROE is termed as the percentage rate of return on each unit of equity invested by bank's shareholders (Kumbirai and Webb, 2010).

\section{Method}

\subsection{Population and sample}

An investigation was conducted that has a quantitative approach because it is based on numerical measurement; and it is of applied type because it was developed based on existing theory. The level of research is correlational for the purpose of determining the relationship between the level of compliance with good corporate governance practices and the profitability of the Banks of Peru for the period 2009 - 2018.

The population consisted of 16 banking entities, listed on the pages of the Lima Stock Exchange (BVL), Superintendence of Stock Market (SMV) and the Superintendence of Banking and Insurance (SBS) (regulatory entities of companies in Peru). Companies that had the required updated information were included and the remaining two were excluded, because they did not have the necessary data for the investigation. A sample size of 13 companies was estimated, selected because they had the relevant data.

\subsection{Data collection instrument}

Data was obtained from the Lima Stock Exchange, about the Good Corporate Governance of banking entities (right to shareholders, general meeting of shareholders, the board of directors and senior management, risk and compliance, transparency of information) established by the Superintendence of Stock Market (2013). Based on the initial information, the reliability analysis was performed on the pillars that make up the code, three were chosen, whose information in the information portals was found in its entirety and was considered reliable and you will see by origin of the same for the years 2009 - 2018 . Also, for the application of profitability the information of the financial statements provided by the regulatory entities was used. The leverage control variable was used to adjust the results.

\subsubsection{Study variables}

The use of financial ratios and the definition of the study variables are based on the Lima Stock Exchange (2013) and the Superintendence of Stock Market (2013).

Table 1

Study variables

\begin{tabular}{|c|c|c|c|}
\hline \multicolumn{4}{|c|}{ Independent variable: Good Corporate Governance } \\
\hline P1 & Shareholder Law & $\begin{array}{l}\text { - } \quad \text { Parity of treatment. } \\
\text { - } \quad \text { No dilution in the share capital share. } \\
\text { - Information and communication to shareholders. } \\
\text { - Participation in dividends of the company. } \\
\text { - } \quad \text { Change or takeover. } \\
\text { - Arbitration for dispute resolution. }\end{array}$ & $\begin{array}{l}\text { (Bolsa de Valores de Lima, } \\
\text { 2013) }\end{array}$ \\
\hline $\mathrm{P} 2$ & General meeting of shareholders & $\begin{array}{l}\text { - Function and competence. } \\
\text { - General Shareholders Meeting Regulations. } \\
\text { - } \text { Pall mechanisms. } \\
\text { - Procedures for exercising the vote. } \\
\text { - Delegation of vote. } \\
\text { - Follow-up of agreements of the General Sharehold- } \\
\text { ers Meeting. }\end{array}$ & $\begin{array}{l}\text { (Bolsa de Valores de Lima, } \\
\text { 2013) }\end{array}$ \\
\hline P5 & Information transparency & $\begin{array}{l}\text { - Information policy. } \\
\text { - } \quad \text { Informancial statements and annual report. } \\
\text { ments between shareholders. } \\
\text { - Corporate governance report. }\end{array}$ & $\begin{array}{l}\text { (Bolsa de Valores de Lima, } \\
\text { 2013) }\end{array}$ \\
\hline \multicolumn{4}{|c|}{ Dependent variable: Profitability } \\
\hline ROE & Profitability by equity & Annual Net Income / average equity. & $\begin{array}{l}\text { (Aebi, Sabato, \& Schmid, } \\
\text { 2012) }\end{array}$ \\
\hline \multicolumn{4}{|c|}{ Control variable: Leverage } \\
\hline APA & Leverage & $\begin{array}{l}\text { Total liabilities / (Share capital + Reserves (number of } \\
\text { times)) }\end{array}$ & (Vera, 2002) \\
\hline
\end{tabular}




\subsubsection{Econometric Model}

The econometric model used is based on two main estimation techniques: in fixed effects and random effects. Through the Hausman test, the most appropriate estimation technique for the investigation was determined.

where:

$$
R O E_{i t}=\beta_{0}+\beta_{1} P 1_{i t}+\beta_{2} P 2_{i t}+\beta_{3} P 5_{i t}+\beta_{4} A P A_{i t}+\varepsilon_{i t}
$$

P1: Shareholder Law

P2: General Shareholders Meeting

P5: Transparency of information

APA: Leverage

$\beta_{0}$ : beta coefficient

$\varepsilon_{i t}$ : error term

i: cross section

t: time series dimension

\subsubsection{Hypotheses}

$\mathrm{H}_{1}$ : There is a direct relationship between the right pillar of the shareholders and the return on equity (ROE).

$\mathrm{H}_{2}$ : There is a direct relationship between the general shareholders meeting pillar and the return on equity (ROE).

$\mathrm{H}_{3}$ : There is a direct relationship between the information transparency pillar and the return on equity (ROE).

\section{Results}

\subsection{Descriptive result}

Table 2 details the mean, standard deviation, minimum and maximum of the study variables of the 13 banking entities of Peru, over the period $2009-2018$.

Table 2

Summary of descriptive statistics

\begin{tabular}{|c|c|c|c|c|c|}
\hline Variable & Observations & Mean & Standard Deviation & Min. & Max. \\
\hline ROE & 130 & 17.791 & 9.026 & -10.751 & 37.770 \\
\hline APA & 130 & 10.182 & 3.584 & 2.728 & 24.390 \\
\hline $\mathrm{P} 1$ & 130 & 0.780 & 0.215 & 0.214 & 1.000 \\
\hline $\mathrm{P} 2$ & 130 & 0.556 & 0.188 & 0.250 & 1.000 \\
\hline P5 & 130 & 0.730 & 0.240 & 0.166 & 1.000 \\
\hline
\end{tabular}

For the measure of profitability, the average value of the ROE was 17,791, with a standard deviation of 9,026, indicating a normal distribution. The minimum ROE was $-10.75 \%$, while the maximum was $37.77 \%$. The profitability of equity (ROE) determines the profit that shareholders receive in comparison to the net result obtained after one year, the higher the ratio, the more beneficial it will be for the taxpayer. Likewise, leverage, a control variable used to adjust the results, indicated an average of 10,182 with a standard deviation of 3,584 . The minimum was $2.73 \%$ and the maximum $24.39 \%$, this ratio combined with the capital ratio helps mitigate the systemic risks of the bank. In effect, the results indicate that there is harmony between capital and debt in the banks studied. The average of pillar one, right of the shareholders, was 0.780 . This means that of the total principles that make up the pillar, banks comply with $78 \%$. The standard deviation was 0.215 , obtained a minimum of $21.4 \%$ and a maximum of $100 \%$. The average of pillar two, general meeting of shareholders, was 0.556 . This means that of the total principles that make up the pillar, banks comply with $55.6 \%$. The standard deviation was 0.188 , obtained a minimum of $25 \%$ and a maximum of $100 \%$. The average of pillar five, transparency of information, was 0.730 . This means that of the total principles that make up the pillar, banks comply with $73 \%$. The standard deviation was 0.240 , obtained a minimum of $16.6 \%$ and a maximum of $100 \%$.

\subsection{Correlation coefficient test}

Table 3 shows the correlation coefficient test, to measure the strength of the association between study variables. It is observed that the variables had a certain degree of correlation with respect to ROE. There is a low correlation regarding shareholders' rights $(0.3101)$ and information transparency $(0.3667)$; and very low with respect to the general meeting of shareholders (0.0586). Consequently, the multiple regression model was applied with a significance level of $10 \%, 5 \%$ and $1 \%$. 
Table 3

Correlation results

\begin{tabular}{cccccc}
\hline Variable & ROE & APA & P1 & P2 & P5 \\
\hline ROE & 1 & & & & \\
APA & .2660 & 1 & 1 & 1 & \\
P1 & .3101 & .3271 & .2109 & .3271 & 1 \\
P2 & .0586 & .1533 & .8520 & .2564 & \\
P5 & .3667 & &
\end{tabular}

\subsection{Multiple regression model for $R O A$}

Table 4

Regression results

\begin{tabular}{|c|c|c|c|c|c|c|}
\hline & \multicolumn{3}{|c|}{ Efectos Fijos } & \multicolumn{3}{|c|}{ Efectos aleatorios } \\
\hline & Coeficiente & valor $\mathrm{p}$ & & Coeficiente & P-Value & \\
\hline Constante & 10.4778 & .0083 & $* * *$ & 9.72302 & .0160 & $* *$ \\
\hline P1 & 0.737470 & .8966 & & -.153463 & .9780 & \\
\hline $\mathrm{P} 2$ & -10.7523 & .0242 & $* *$ & -9.26165 & .0355 & $* *$ \\
\hline P5 & 7.90385 & .1390 & & 9.18503 & .0760 & $*$ \\
\hline APA & .682234 & .0106 & $* *$ & .651451 & .0075 & $* * *$ \\
\hline $\mathrm{N}$ & 130 & 130 & & 130 & 130 & \\
\hline $\mathrm{R} 2$ & .599937 & & & & & \\
\hline $\mathrm{CH}$ & & & & & .510345 & \\
\hline
\end{tabular}

According to Hausman's contrast, it is determined that the random effects model would be the best option. In addition, $\mathrm{R}^{2}$ shows that $60 \%$ of the variation in $\mathrm{ROE}$ was driven by regressors.

\section{Discussion}

\subsection{Relationship between shareholders' rights (Pillar 1) and return on equity (ROE)}

The results of the econometric model indicate that there is not enough statistical significance to determine that there is no direct relationship between the right pillar of the shareholders and the return on equity, so another study should be carried out with the use of different control variables, in order to validate the obtained. The literary review, through the Lima Stock Exchange and its study to assess the impact of Corporate Governance on the different stock market variables, suggests that the elaboration of corporate governments in each country follows different methodologies and standards. The characteristics of each country may or may not facilitate the formation and impact of a corporate government on the different financial indicators. Although Peru is governed under a British approach, oriented towards compliance with shareholders' rights and improving relations with interest groups, this does not generate a significant impact on profitability due to inefficiency in the pillar control and evaluation Quality of corporate governance. Being an emerging country, with companies that have been incorporating the code, more rigidity and control are still needed in compliance with it.

\subsection{Relationship between general meeting of shareholders (Pillar 2) and return on equity (ROE)}

There is a significant direct relationship between the general meeting of shareholders and return on equity $(\mathrm{p}<0.05)$. This result indicates that the greater the compliance in banking companies of pillar 2 of good corporate governance, the greater the profitability of equity for shareholders. According to Sohail, Rasul, \& Fatima (2017), in their research, is the internal and external governance mechanism enriching the performance of the Pakistan banking sector? The results show us that the internal mechanisms (board size, participation rate, general meeting of shareholders, administrative property, institutional property, ownership of shares of block holders and financial transparency) and external mechanisms (legal infrastructure and protection of minority shareholders and the corporate control market), are important to accelerate better performance in companies, these mechanisms improve the return on assets (ROA), return on capital (ROE), earnings per share, dividend payment relationships in the banking sector. However, the results do not coincide with the research of Muhammad, Hongxing, Gulzara, Hafiz Mustansar, \& Qurat Ui (2019) entitled Corporate Governance, Political Connections, and Bank Performance, in which it shows that the significant and negative coefficients of the meetings and the board indicates a negative relationship between the board and the profitability of the Pakistani banks. This suggests that an increase in board meetings significantly reduces ROA, ROE, NIM, and PM.

\subsection{Relationship between information transparency (Pillar 5) and return on equity (ROE)}

There is a significant direct relationship between information transparency and equity performance $(p<0.05)$. This result 
indicates that the greater the compliance in banking companies of pillar 5 of good corporate governance, the greater the profitability of equity for shareholders. According to Losada \& Alkire (2019), in their research "The transformative impact of bank transparency on the financial well-being of consumers" shows us in their results that the transparency of banking information can increase the financial well-being of consumers, in addition to the effect Positive transparency of banking information occurs because the shared information improves positive attitudes towards banks and the perceived financial selfsufficiency of customers. This research positively contrasts the results obtained, since many banks aim to increase the transparency of their information without a clear understanding of the effects of these actions on consumers, also in the decisions of their managers by increasing their ROE.

\subsection{Inverse relationship between the average period of accounts receivable and profitability}

The results indicate that there is a negative correlation between the average collection period (PPC) and the profitability of assets (ROA), with a -0.000693844 , which is evidenced in Table 4 . The results about the PPC imply that the shorter the days or the average collection period, the greater the return on assets, this is because in the shortest time available cash is obtained for the company, and that they can be used to invest, comply with obligations or debts. The average for PPC was 78.60 days. This means that companies on average waited an average of 50 days to collect cash from credit sales or that approximately every 50 days they receive payments from their customers. This implies that companies in the industrial sector improve their profitability when the time in days to make their payments to customers is less.

\subsection{Direct relationship between the average period of accounts payable and profitability}

The results indicate that there is a positive correlation between the average payment period (PPP) and the profitability of assets (ROA), with a 0.000249050 , which is shown in Table 4. The average PPP was 54 days, which means that payments to suppliers are made on average every 54 days, which also implies that companies in the industrial sector should not take into account the analysis of accounts payable to improve their operating margin. According to Penfold, Oneto \& Rodriguez (2015), the board must have the power and self-sufficiency, such as the balance of knowledge and experience that allows it to define independently, safely and with a long-term objective the policy directions raised by which the management administration will be examined. Consequently, the fifth pillar intends to examine the mechanisms where the Board of Directors is structured, the development of designation of the members of the board of directors, if the ideal characteristics for its selection are taken into account, if it establishes removal mechanisms, if it establishes the determined time of the position and if the Board of Directors is gradually nominated. Likewise, if the directory profile information and the existence of autonomous directors are structured. Nur (2019) also concludes that Good Corporate Governance does not affect the profitability of Islamic banking entities (ROE), which means that the better the score of the Good Corporate Governance indicator, the lower the value of (ROE), does not guarantee the bank's profitability increase.

From which it is concluded that in an econometric way the impact of good corporate governance is positive and especially significant. Through the estimation of elasticities, it was found that, with respect to the other variables, corporate governance has a greater impact on the profitability variables. The better management of good corporate governance, the greater the profitability in companies.

\section{Conclusions}

Through the econometrics model the relationship between the pillars general meeting of shareholders and transparency of the information with the profitability by equity of the banks of Peru has been evidenced. Although the pillar of shareholders' rights has a negative relationship with the return on equity, according to what is obtained in the model, it cannot be considered significant. For this reason, other economics variables should be considered for future research. As for the aforementioned, it is deduced that it is essential to have a good business management complying with the principles already referred to above of corporate governance; providing the investor with confidence, as well as consequently reducing the effect of bad decisions on their part, poor administrative management and mitigating agency problems; giving them the authority and self-sufficiency of being able to have truthful and transparent knowledge of the policy guidelines set forth in the management administration. This has a positive impact on ROE, as well as the economic benefits of banking companies. In addition to increasing the efficiency of the economy, there is a need for strengthening the economic growth of the country. Although the model based on which the code of good Peruvian corporate governance was developed is British, the national situation influences the results. More control and supervision of each of the principles proposed in the pillars is necessary. Although most of the preliminary results are as planned, it is necessary to carry out a study with the use of more control variables that allow for better routing of the relationship between the pillars and profitability. It is worth mentioning that companies in Peru are just incorporating the use of the code of good corporate governance, and that the study focused on the banking sector and only developed three pillars of the five proposed.

\section{Acknowledgement}

The authors would like to thank the anonymous referees for constructive comments on earlier version of this paper. 


\section{References}

Aebi, V., Sabato, G., \& Schmid, M. (2012). Risk management, corporate governance, and bank performance in the financial crisis. Journal of Banking \& Finance, 36(12), 3213-3226.

Arniati, T., Puspita, D. A., Amin, A., \& Pirzada, K. (2019). The implementation of good corporate governance model and auditor independence in earnings' quality improvement. Entrepreneurship and Sustainability Issues, 7(1), $188-200$.

Arrarte, R. (2019). Razones por las que entender la importancia de establecer marcos sobre Gobierno Corporativo, riesgo y cumplimiento. España: Diligent.

Babalola, Y. A. (2012). The determinants of bank's profitability in Nigeria. Journal of Money, Investment and Banking, 24, 616.

Banco Central de Reserva del Perú. (2018). Memoria 2018. Lima.

BCBS (1999). Enhancing Corporate Governance for Banking Organisations. Basel: Bank for International Settlements.

BCBS (2006). Enhancing Corporate Governance for Banking Organisations. Basel: Bank for International Settlements.

Black, B., Carvalho, A., \& Gorga, É. (2010). Corporate governance in Brazil. Emerging Markets Review, 11(1), 21-38. doi:10.1016/j.ememar.2009.09.004

Bolsa de Valores de Lima. (2013). Código de buen gobierno corporativo para las sociedades peruanas. Lima, Perú. Recuperado de http://www.bvl.com.pe/mercempresas.html.

Bolsa de Valores de Lima. (2013). Sobre el índice de buen gobierno corporativo. Obtenido de Suplemento: https://www.bvl.com.pe/ipgc/suplemento.pdf

Casas Tragodara, C. (2018). Impacto del Buen Gobierno Corporativo en diferentes variables Bursátiles. Lima.

Kengkathran, S. (2019). Environmental, social and governance disclosure and its impact on financial performance of Top 100 companies in Malaysia and Australia. International Journal of Engineering and Advanced Technology (IJEAT), 9(1), 35793584. doi:10.35940/ijeat.A2691.109119

Kumbirai, M., \& Webb, R. (2010). A financial ratio analysis of commercial bank performance in South Africa. African Review of Economics and Finance, 2(1), 30-53.

Laffaye, S. (2008). La crisis financiera: Origen y perspectivas. CEI, 13, 1-21.

Losada-Otarola, M., \& Alkire, L. (2019). el impacto transformador de la transparencia bancaria en el bienestar financiero de los consumidores. Scopus, 1062-1079.

Mohamad Kamal, M. E., Md Salleh, M. F., \& Ahmad, A. (2019). Management fraud propensity factors, governance interactions and earnings manipulation: a Case of Malaysian Public Listed Companies. Intelligence Engineering \& Sciences Publication, 8(3), 8649-8663. doi:10.35940/ijrte.C6455.098319

Muhammad, H., Hongxing, Y., Gulzara, T., Hafiz Mustansar, J., \& Qurat Ui, A. (2019). Corporate governance, political connections, and bank performance. International Journal of Financial Studies, 7 (4) 62.

Nur Fitriana, H. (2019). The impact of good corporate governance and Sharia compliance on the profitability of Indonesia's Sharia banks. Business Perspectives, 17(1) 56-66.

OECD (1999). Principles of Corporate Governance. Paris: OECD.

OECD, O. (2004). The OECD principles of corporate governance. Contaduría y Administración, (216).

Ongole, V. \& Kusa, G. (2013). Determinants of the financial performance of commercial banks in Kenya. International Journal of Economics and Financial Issues, 3, 237-252.

Organización para la Cooperción y Desarrollo Económico. (2016). Principios de Gobienro Corporativo de la OCDE y de la G20. Paris: Editions OCDE.

Obtenido de https://www.oecd.org/daf/ca/corporategovernanceprinciples/37191543.pdf

Ortiz, J. J. M. (2014). Gobierno corporativo en el Perú: contribución para re-enfocar el concepto. Apuntes: Revista de Ciencias Sociales, (56/57), 95-114.

Pham, Q., Ho, T., Pham, D., \& Nguyen, H. (2020). Effects of corporate governance on high growth rate: evidence from Vietnamese listed companies. Management Science Letters, 10(7), 1553-1566.

Penfold, M., Oneto, A., \& Rodríguez Guzmán, G. (2015). № 20. La transparencia del gobierno corporativo en las Empresas de Propiedad del Estado en América Latina.

Rizqiani Rusydi, A., Palutturi, S., Bahry Noor, N., A. Pasinringi, S., Multazam, A., Zuardin, .. . Yani, A. (2019). Application of good corporate governance principles in public regional hospital of Haji, Makassar. International Journal of Innovative Technology and Exploring Engineering, 9(1), 805-808. doi:10.35940/ijitee.A4309.119119

Rokibul Kabir, M., Sobhani, F., Omar, N., \& Mohamad, N. (2019). Corporate governance and risk disclosures: A comparative analysis between Bangladeshi and Malaysian Islamic banks. International Journal of Financial Research, 10(5), $110-125$. doi:https://doi.org/10.5430/ijfr.v10n5p126

Sohail, S., Rasul, F., \& Fátima, U. (2017). Is internal and external mechanism of governance enriching the performance of the banking sector of Pakistan? Corporate Governance (Bingley), 17(4), 629-642.

Superintendencia del Mercado de Valores. (2014). Código del Buen Gobierno Corporativo para las Sociedad Peruanas. Lima. Vera, G. B. (2002). El estudio de apalancamiento como metodologia de analisis de la Gestion en la empresa. Redalyc, 65-91.

Yatim, N., \& Yusoff, H. (2014). Governance structure and practice in Malaysia: Board of directors' role and responsibilities. In Corporate Governance (pp. 199-228). Springer, Berlin, Heidelberg. 
(C) 2020 by the authors; licensee Growing Science, Canada. This is an open access article distributed under the terms and conditions of the Creative Commons Attribution (CC-BY) license (http://creativecommons.org/licenses/by/4.0/). 